\title{
ASSESSMENT OF FOOD SECURITY STATUS OF REFUGEES IN TURKEY USING FAO'S FOOD INSECURITY EXPERIENCE SCALE Abdulrazak Ghazal ${ }^{*}$, Mehmet Bozoglu ${ }^{2}$
}

\author{
${ }^{1 * 2}$ Ondokuz Mayis University, Faculty of Agriculture, Department of Agricultural Economics, 55139, Samsun, Turkey.
} Email: ${ }^{1 *}$ ashak7@yahoo.com, ${ }^{2}$ bozoglumehmet@gmail.com

Article History: Received on $9^{\text {th }}$ March 2021, Revised on $28^{\text {th }}$ April 2021, Published on $29^{\text {th }}$ April 2021

\section{Abstract}

Purpose of the study: This study aims to assess the food security status among Syrian and Iraqi refugees in Samsun, Turkey. In addition, to examine the association between refugees' profiles and food security status.

Methodology: We surveyed 252 households through face-to-face and semi-structured questionnaires; these tools were used in data collection between 2019-2020. FAO's scale, descriptive analysis, and Chi-square test were conducted to achieve the objectives of this study.

Main Findings: The findings indicated that the majority of refugees households, $60 \%$ experienced food insecurity. The results indicated that $30 \%$ of Syrian and $47 \%$ of Iraqi refugees were food security. Food security was significantly influenced by several socio-demographic ( 7 variables) and economic variables (9 variables).

Applications of this study: This paper provides implications for policymakers and refugees. The current study recommends applying specific programs that could alleviate food insecurity among refugees. The policymakers should improve the economic status of refugees' households, especially the most vulnerable. Likewise, the policies in this field should be built by understanding the factors influencing food security.

Novelty/Originality of this study: The current study is considered one of the pioneering and important studies in the food security field for refugees in Turkey. No studies have been conducted to assess food security for refugees. It seems to be important to review and re-evaluate the Turkish policies associated with refugees in Turkey.

Keywords: Food Security, Domains, Refugees, Syrian, Iraqi, Turkey.

\section{INTRODUCTION}

The number of refugees and hungry people is still increasing in the world because of economic and political status. 821 million hungry people live in the world (WFP, 2019). The number of refugees in the world increased from 14 to 25.9 million during the last two decades (IOM, 2020). In Turkey, over 3.8 million individuals hold refugee status, making Turkey the largest refugee population in the world (UNHCR, 2019). Syrian and Iraqi refugees represent the largest group of recent immigrants into Turkey.

The refugees in Turkey are facing different challenges, which in turn affect the daily activities of the refugees. Migration to another country has an important impact on food security due to new social and economic status. Refugees in new environments face difficulties adapting to a new food, values, and culture (Carroll et al., 2007). Food insecurity status encourages people to migrate into a new society (Sadiddin et al., 2019). Political instability and bad economic situations are the main challenges to food security (Woertz, 2017). Different factors cause food insecurity statuses, such as poor work skills, experience, and sufficient literacy. These factors prevent refugees from gaining employment or good work (Nunnery and Dharod, 2017; Smith et al., 2017). Refugees are a potentially vulnerable group and need more levels of monitoring of their health (Hadley \& Sellen, 2006).

According to (FAO, 2009), food refers to any substance intended to be or expected to be ingested by humans, which these substances provide the necessary nutrients to survive in life. Food security and hunger are two associated terms. The term hunger may be closer to the term food insecurity. Food insecurity or hunger refers to if a household is unable to get enough food to eat. Food insecurity or hunger refers to if a household is unable to get enough food to eat. Moreover, food insecurity represents a major public health concern and is considered an index of health and well-being (Alaimo et al., 2001). Different studies confirm the association between food security and health outcomes and nutritional risks (Vilar-Compte et al., 2017).

There are no constant measurements of food security or food insecurity. Due to various factors are associated with the food security phenomenon, as a consequence, measuring food insecurity represents a challenge. Therefore, researchers and agencies have been using the Household Food Security Supplemental Module. Different methods have been proposed to measure food security at the household level. Different organizations developed food security measures that estimate food security at the household level. FAO's food insecurity experience scale is considered the most common measure to assess food insecurity at an individual level. The FIES measure food insecurity at an individual level (Allee et al., 2021). This scale was applied in more than 140 countries, and efforts continue to develop this scale (Saint Ville et al., 2019). This scale is available in more than 200 languages throughout the world (Frongillo et al., 2017). 
The research problem in this study is organized from different literature in the field of food security. In addition, to assess the food security status of both Syrian and Iraqi refugees living in Samsun city using the FIES indicators. To date, no study aimed to understand the food security of Syrian and Iraqi refugees in Turkey. This study chooses Syrian and Iraqi refugees because they are the largest refugee group living in Samsun city.

The objectives of the current study are:

1. To explore the socio-demographic and economic variables of the refugees.

2. To assess the food security level of refugees.

3. To identify the associations between food security status and refugees.

The study hypotheses were based on the research objectives and questions. In general, these hypotheses aimed to examine if there were statistically significant associations among variables.

H1: There is a significant difference in food security status between Syrian and Iraqi refugees.

H2: Socio-demographic variables have a significant influence on food security.

H3: Economic variables have a significant influence on food security.

\section{LITERATURE REVIEW}

Food security is measured to reduce the number of hungry and assure all people have enough to eat. The concept of food security originated in 1970 during the global food crisis. Food security is focused on ensuring food availability and the price stability of basic foods (Berry et al., 2015). In 1980 food security concept was considered an important mainstay in the development process. In 1990 continued to grow after the crises in Africa.

Food security has become a fundamental subject for all governments in the world through the last decades. The climatic changes, dropping in the agricultural lands, and rising food prices have negatively affected the level of food security. The food security field is common more in both developing countries and host countries of refugees. For two decades until now, there were many definitions for food security in published researches, but we can say that FAO food and agriculture organization definition is the current widely accepted definition. According to FAO, food security is a situation that exists when all people, at all times, have physical, social, and economic access to sufficient, safe, and nutritious food that meets their dietary needs and food preferences for an active and healthy life (FAO, 2009). In 2009 is added another dimension to this definition this dimension is stability (FAO, 2009). Therefore, food security was defined by FAO depending on four dimensions: availability, accessibility, utilization, and stability.

Availability of food refers to the availability of food produced locally or imported from abroad. Accessibility, people or consumers can reach the wanted food at all-time (physical access); also, consumers have enough money for purchase (economic access). Utilization, a consumer must be able to consume suitable food in quantity and quality form. The food consumed by people must be safe, clean, and healthy. Stability ensures no change in consumed amounts through emergency conditions such as natural disasters (climate, earthquake) or those that are man-made (war, economic crises). Recently, a new dimension has appeared; this dimension is the importance of sustainability. Sustainability involves many indicators such as ecology, biodiversity, climate changes, cultural and economic factors; we can note that this dimension may affect the food security of future generations (Peng and Berry, 2018). It is concluded that the presence of one dimension does not ensure another dimension. (Ifeoma and Agwa, 2014) indicated that food availability does not mean food accessibility. (Farrukh et al., 2020) referred to that food security can be found in two levels macro-level (national) and micro-level (household and individual). Availability dimension exists at a national level, accessibility exists at a household level, utilization diminution exists at an individual level, and stability exists at a time level (FAO, 2009). Improvements in the availability and accessibility dimensions get benefits for individuals, communities, and countries (Melgar-Quinonez and Hackett, 2008).

When we review the literature related to food security, we notice that the majority of these studies were concentrated either in developing countries or countries that received refugees. Different economic variables affect food insecurity, such as unemployment, low income, and tax rates (Shobe et al., 2018). There is a relationship between the prevalence of food security and household variables. (Smith et al., 2017) suggested that women and older people were more likely to experience food insecurity. (Vilar-Compte et al., 2017) referred to that food security can be determined by age, gender, health status, and income. (Mota et al., 2019) reported that family size, age, and non-educated household heads negatively influenced food security. Similar findings were reported where the higher the household head's land size, household size, and education level, the less food insecure (Yikii et al., 2017). The reason for food insecurity in older adults is the poor nutritional status (Fernandes et al., 2018). (Ramakrishna and Demeke, 2002) revealed that cereal production, education level, increase in fertilizer application positively influenced food security while the family size influenced food insecurity positively. While (Ajani et al., 2006) identified that income and education levels influence food security positively. The role of women in households also plays an important impact on food security. (Larson et al., 2019) revealed that a more diverse diet happens for females who can control over income. Also, decision-making for women in household purchases was associated with dietary diversity (Amugsi et al., 2016; Sinharoy et al., 2019). 
Moreover, women's empowerment positively impacts food security for them and household members (Galiè et al., 2019; Asadullah \& Kambhampati, 2021; Price et al., 2018).

The measurement of food security for immigrants differs from others who are in their country. Moreover, the assessment of food security associates with the population subgroup. (Vilar-Compte et al., 2017) tried to understand food insecurity among older adults. According to the findings, food security can be determined by age, gender, health status, and income. Food security governance can be improved by the identification of useful FI indicators for policymakers (PérezEscamilla et al., 2017). Food insecurity is associated with the region and depends on regional context (Pereira et al., $\underline{2021)}$.

Different studies were conducted to measure the food security of refugees in host countries. (Dharod et al., 2013) suggested that food insecurity among Somali refugees consumed fruit and vegetables less and intake of meat and eggs was higher. In addition, the intake of fruit and vegetables was lower among the food insecure refugees. (Omidvar et al., 2013) indicated that food insecurity was relevant in female-headed households, households whose head and spouse had a lower level of education, illegal residential status, unemployment, and low socioeconomic status for Afghan refugees. Generally, the proportion of food insecure people is more common in rural areas due to low income and poor socioeconomic conditions (Iorlamen et al., 2014). (Hadley et al., 2007) reported that food insecurity of Liberian refugees in the USA was more likely to be indicated in households with lower income and lower education.

Expenditure on food, or is called the food security index, is also considered a method to measure the food security status. Households were grouped into food secure and food insecure using food security status. (Iorlamen et al., 2014) assessed the food security level in Nigeria through the connection between expenditure on the households' food and food security status. According to the results, the household that spent at least $93.5 \$$ monthly is categorized as food secure, while the households that spent below this value are categorized as food insecure. (Ifeoma and Agwa., 2014) assessed the food security status among farming households in rural areas, Nigeria. The results indicated that households whose food expenditure per capita was less than N2,694.954 were considered food insecure and vice versa. The findings also suggested three factors have significant effects on food security education level, household size, and access to credit. (Titus and Adetokunbo, 2007) assessed food security situation among Nigerian urban households using the food security index. According to results, a household whose food expenditure per capita equals or greater than N 7,967.19 was classified as a food-secure household. The study suggested that food security increases with an increase in the level of education.

\section{METHODOLOGY}

\section{Case Study}

This study was carried out in Samsun, Turkey, to assess the food security status among Syrian and Iraqi refugees. Samsun is one of the 81 states in Turkey. It was located on the black sea northerly. The research area Samsun province included three main districts Atakum, Ilkadim, and Canik. Our study focused on collecting the needed data from these three districts.

\section{Sampling}

A sample of 252 includes refugee respondents who were responsible for food buying in their households (with age 18 years and above). The random sampling design was to choose a sample among refugees living in three districts in Samsun city.

\section{Development Questionnaire and Semi-Structured Interview}

The researcher designed the questionnaire according to the objectives of the study. The questionnaire of the study includes information on socio-demographic, economic variables, and indicators of three domains. These indicators include two responses yes (indicates food secure) and no (indicates food insecure). Arabic is the mother language for Iraqi and Syrian refugees, so the questionnaire and semi-structured interview in this study was conducted in the Arabic language. The simplicity and clarity of questions were important points which the researcher has focused on them.

\section{Data Collection}

The needed data were collected between October 2019 and February 2020 by the researcher $(n=252)$. Face-to-face, semistructured interviews, and structured questionnaires were the main sources for data collection. The interview lasted 60 minutes and was conducted on holidays. The data collection was done at the respondents' homes and general places. Primary and secondary data were used in the current study. Primary data is the main source to conduct our study. Secondly, Secondary data was necessary to estimate the number of refugees living in Samsun, Turkey.

\section{The Study Variables}

The current study includes two main variables: dependent variables and explanatory variables. The dependent variable represents the food security status of refugees where 1 refers to food security and 0 refers to food insecurity. And, 
explanatory variables represent common food security determinants that include two groups: socio-demographic variables (12 variables) and economic variables (10 variables).

\section{Measurement Of Food Security}

USAID's Food and Nutrition Technical Assistance (FANTA) project developed a scale to measure food insecurity status; this scale is called HFIAS (Household Food Insecurity Access Scale). This scale was used in the current study to measure the food security status of Syrian and Iraqi refugees in Samsun, Turkey. In general, the HFIAS scale includes three domains and nine items. Simple modifications have been done to the scale to comply with the food security dimensions stipulated in the FAO definition. This scale included nine questions distributing among three domains: uncertainty domain (one question), insufficient quality (three questions), and insufficient food (five questions). Each question in the scale includes two options a score of 1 classified household into secure and a score of 2, which refers to an insecure household. As a result, households were classified into two groups: food secure and food insecure.

\section{Statistical Analysis}

Chi-square test of independence was used to test the relationship between different variables (socio-demographic and economic variables) and food security. The dependent variable (food security status) consists of two values; the first one $=1$ indicates food-secure, whereas the second one $=0$ indicates food insecurity. In addition, the Chi-square test is used to find out if there are differences among groups and whether these differences are significant. The results were considered statistically significant at the $1 \%, 5 \%$, and $10 \%$ levels.

\section{RESULTS OF THE STUDY}

\section{Profile of respondent}

One of the current study objectives is to understand the respondent's profile. This analysis includes socio-demographic and economic variables.

\section{Socio-Demographic Variables}

Table 1 below shows a descriptive analysis of our sample, including socio-demographic variables. The results of the analysis indicated $44.8 \%$ were Syrian $55.2 \%$ Iraqi. Males $62.3 \%$ were more than females $37.7 \%$. In addition, $51.2 \%$ were married, $47.2 \%$ were single, and only $1.6 \%$ were divorced. The household size indicated that $37.7 \%$ had $5-6$ members, $25.4 \%$ had 3-4 and more than 6 members, and $11.5 \%$ had less than 3 members. According to males in the household, $47.6 \%$ had less than $3,43.3 \%$ had $3-4$, and $9.1 \%$ had more than 4 . Out of respondents, $58.3 \%$ had less than 3 females, $33.3 \%$ had 3-4, and $8.3 \%$ had more than 4 females. The age of respondents ranged from 18 to 80 years; the average was 30 years. The majority of respondents, $47.2 \%$ had a four-year degree, $21.8 \%$ had high school, $14.3 \%$ reported postgraduate. The majority of the households, $90.9 \%$ lived alone at home, $7.1 \%$ reported two households, and $2 \%$ reported three households at the same home. $36.9 \%$ had lived in Turkey for more than 5 years, $32.5 \%$ less than two years, and $30.6 \%$ had lived for from $3-4$ years. $67.9 \%$ of respondents had members in their countries, and $32.1 \%$ had not. The majority settled in the center of Ilkadim, $61.1 \%, 20.6 \%$ in Atakum, and $18.3 \%$ settled in Canik.

Table 1: Socio-demographic variables $(\mathrm{n}=252)$

\begin{tabular}{llll}
\hline Socio-demographic variables & Sub-variables & $\begin{array}{l}\text { No. of } \\
\text { respondents }\end{array}$ & Percent \% \\
\hline Nationality & Syrian & 113 & 44.8 \\
& Iraqi & 139 & 55.2 \\
\hline Gender & Male & 157 & 62.3 \\
& Female & 95 & 37.7 \\
\hline Marital status & Married & 129 & 51.2 \\
& Single & 119 & 47.2 \\
& Divorced & 4 & 1.6 \\
\hline Household size & Less than 3 & 29 & 11.5 \\
& From 3 to 4 & 64 & 25.4 \\
& From 5 to 6 & 95 & 37.7 \\
& More than 6 & 64 & 25.4 \\
\hline Number of males & Less than 3 & 120 & 47.6 \\
& From 3 to 4 & 109 & 43.3 \\
& More than 4 & 23 & 9.1 \\
\hline Number of females & Less than 3 & 147 & 58.3 \\
& From 3 to 4 & 84 & 33.3 \\
& More than 4 & 21 & 8.3 \\
\hline Age group & $18-25$ years & 100 & 39.8 \\
& 26 - 35 years & 79 & 31.5 \\
& 36 - 45 years & 44 & 17.5 \\
\hline
\end{tabular}




\begin{tabular}{llll}
\hline & More than 45 & 29 & 11.2 \\
\hline Level of education & Illiterate & 13 & 5.2 \\
& Primary & 13 & 5.2 \\
& Secondary & 16 & 6.3 \\
& High school & 55 & 21.8 \\
& University & 119 & 47.2 \\
& Postgraduate & 36 & 14.3 \\
\hline Household number & 1 household & 229 & 90.9 \\
& 2 households & 18 & 7.1 \\
& 3 households & 5 & 2 \\
\hline Length of stay in Turkey & Less than 3 years & 82 & 32.5 \\
& From 3 to 4 years & 77 & 30.6 \\
& Above of 5 years & 93 & 36.9 \\
\hline Do you have family in your country? & Yes & 171 & 67.9 \\
& No & 81 & 32.1 \\
\hline District & Canik & 46 & 18.3 \\
& Ilkadim & 154 & 61.1 \\
& Atakum & 52 & 20.6 \\
\hline
\end{tabular}

Source: Authors

\section{Economic Variables}

Table 2 below shows a descriptive analysis of our sample concerning economic variables. $35.7 \%$ were students, $38.5 \%$ were employed, and $25.8 \%$ were unemployed. The number of household workers indicates that $51.2 \%$ had not workers, $32.9 \%$ had one worker, $13.5 \%$ had two workers, and $2.4 \%$ had three workers. $36.1 \%$ indicated that income was greater than 3000TL, 29\% between 2000-3000, 18.7\% between 1500-2000, and $16.3 \%$ less than 1500 TL per month. The majority of respondents, $84.9 \%, 89.7 \%$, do not receive any cash or kind assistance, and $15.1 \%, 10.3 \%$ received respectively. The majority of respondents, $79 \%$, did not work in their career, whereas $21 \%$ had worked. After inflation, $70.2 \%$ of respondents had been changed their consumption, and $29.8 \%$ had not. $86.5 \%$ had no vehicle, and $13.5 \%$ had. The majority of respondents, $79 \%$, had every item in their houses, whereas $21 \%$ had not. Finally, $49.6 \%$ of respondents eat three meals, $43.7 \%$ eat two, and $6.7 \%$ eat four meals daily.

Table 2: Economic variables $(n=252)$

\begin{tabular}{llll}
\hline Economic variables & Sub-variables & $\begin{array}{l}\text { No. of } \\
\text { respondents }\end{array}$ & Percent \% \\
\hline Job-status & Unemployed & 65 & 25.8 \\
& Employed & 97 & 38.5 \\
& Student & 90 & 35.7 \\
\hline Number of workers & None & 129 & 51.2 \\
& 1 worker & 83 & 32.9 \\
& 2 workers & 34 & 13.5 \\
& 3 workers & 6 & 2.4 \\
\hline Monthly income & Less than 1500 TL & 41 & 16.3 \\
& 1500 -2000 TL & 47 & 18.7 \\
& $2000-3000$ TL & 73 & 29.0 \\
& More than 3000 TL & 91 & 36.1 \\
\hline Cash assistance & Yes & 38 & 15.1 \\
& No & 214 & 84.9 \\
\hline Kind assistance & Yes & 26 & 10.3 \\
& No & 226 & 89.7 \\
\hline Career & Yes & 53 & 21 \\
& No & 199 & 79 \\
\hline Consumption change & Yes & 177 & 70.2 \\
& No & 75 & 29.8 \\
\hline Vehicle & Yes & 34 & 13.5 \\
& No & 218 & 86.5 \\
\hline Item & Yes & 199 & 79 \\
& No & 53 & 21 \\
\hline N. of meal in Samsun & Two meals & 110 & 43.7 \\
& Three meals & 125 & 49.6 \\
& Four meals & 17 & 6.7 \\
\hline
\end{tabular}


Source: Authors

\section{Measurement of Food Security}

The assessment of the refugees' food security is the main aim of this study. Three different domains of food insecurity were used to assess the refugees' food security situation. The first domain, anxiety, and uncertainty include one question that represents the level of food security concerning food supply. The second domain, insufficient quality (includes three questions representing the level of food security concerning variety and preference. The third domain, insufficient food intake, includes five questions. Finally, the total level of food security includes three previous domains or nine questions.

\section{Anxiety and Uncertainty Domain}

Anxiety and uncertainty consist of one indicator developed by USAID with two frequency food secure and food insecure. Table 3 below shows the results of the anxiety and uncertainty domain. The results indicate that out of 252 respondents, $67.3 \%$ of respondents were not worried about the amount of enough food, whereas $32.7 \%$ were worried.

\section{Insufficient Quality Domain}

The second domain, insufficient quality, includes three questions. The results in table 3 indicate that out of 252 respondents, $81.3 \%$ of respondents got sufficient food quality during the year, and $18.7 \%$ did not get it. $61.8 \%$ of respondents were able to eat preferred food, and $38.2 \%$ were not able to eat preferred food. $66.1 \%$ were able to eat desired food, whereas $33.9 \%$ were not able to eat desired food.

\section{Insufficient food domain}

The third domain, insufficient food intake, includes five questions. According to the findings in table 3 , $86.5 \%$ of respondents got sufficient food quantity during the year, and $13.5 \%$ did not get it. $76.1 \%$ of respondents had sufficient money to buy sufficient food or eat the desired meal, whereas $23.9 \%$ did not have sufficient money to buy sufficient food or eat the desired meal. $81.3 \%$ of respondents did not go to sleep hungry because of no food to eat, whereas $18.7 \%$ went to sleep hungry. $80.5 \%$ of respondents had a way to get food or did not remain without eating a whole day and night, and $19.5 \%$ had no way to get food or remained without eating a whole day and night. Finally, $79.3 \%$ had easy access to food markets, whereas $20.7 \%$ had no easy access to food markets.

Table 3: FAO Food Insecurity Experience Scale (FIES)

\begin{tabular}{|c|c|c|}
\hline \multirow[t]{2}{*}{ The scale (FIES) questions } & \multicolumn{2}{|c|}{ Food security status } \\
\hline & Food secure \% & Food insecure\% \\
\hline \multicolumn{3}{|c|}{$\begin{array}{l}\text { The first domain: Anxiety and uncertainty about the } \\
\text { household food supply }\end{array}$} \\
\hline $\begin{array}{l}\text { In the last year, did you worry that your household would } \\
\text { not have enough food? }\end{array}$ & 67.3 & 32.7 \\
\hline \multicolumn{3}{|l|}{ The second domain: Insufficient Quality } \\
\hline $\begin{array}{l}\text { Does your household get sufficient quality food during the } \\
\text { year? }\end{array}$ & 81.3 & 18.7 \\
\hline $\begin{array}{l}\text { In the last year, did you or any household member not } \\
\text { have been able to eat the kinds of foods you preferred } \\
\text { because of the lack of resources? }\end{array}$ & 61.8 & 38.2 \\
\hline $\begin{array}{l}\text { In the last year, did you or any household member have to } \\
\text { eat some foods that you did not want to eat because of the } \\
\text { lack of resources? }\end{array}$ & 66.1 & 33.9 \\
\hline \multicolumn{3}{|l|}{ The third domain: Insufficient food } \\
\hline $\begin{array}{l}\text { Does your household get available or sufficient food } \\
\text { quantity during the year? }\end{array}$ & 86.5 & 13.5 \\
\hline $\begin{array}{l}\text { Do you have enough money to buy sufficient food or to eat } \\
\text { the desired meal? }\end{array}$ & 76.1 & 23.9 \\
\hline $\begin{array}{l}\text { In the last year, were you or any household member go to } \\
\text { sleep hungry because of no food to eat? }\end{array}$ & 81.3 & 18.7 \\
\hline $\begin{array}{l}\text { Did you or any household member have no way to get } \\
\text { food or remained without eating a whole day and night in } \\
\text { the last year? }\end{array}$ & 80.5 & 19.5 \\
\hline Do you have easy access to the food market? & 79.3 & 20.7 \\
\hline
\end{tabular}

Source: Authors 


\section{Total food security}

Total food security status was estimated through a combination of the three domains presented above. For instance, to estimate total food security, three stages were done: firstly, it is estimated at indicator level secondary, is estimated at the domain level, and finally is estimated at the total level. Table 4 and figure 4 below illustrate the food security status at these levels. More than $67 \%$ of the refugees experienced food security status at anxiety and uncertainty domain, $52.2 \%$ and $56.6 \%$ of the refugees experienced food security status at the insufficient quality and insufficient food domains, respectively. Finally, approximately $40 \%$ of the households experienced food security status after a combination of three domains. It is concluded from tables 3 and 4 that the proportion of food security decreases gradually when moving from indicator to domain and then to total level.

Table 4: Food security results according to domain

\begin{tabular}{lll}
\hline \multirow{2}{*}{ Domain } & \multicolumn{2}{l}{ Food security status } \\
\cline { 2 - 3 } & Food- secure\% & Food- insecure\% \\
\hline Anxiety and uncertainty & 67.3 & 32.7 \\
\hline Insufficient quality & 52.2 & 47.8 \\
\hline Insufficient food & 56.6 & 43.4 \\
\hline Total & 39.7 & 60.3 \\
\hline
\end{tabular}

Source: Authors

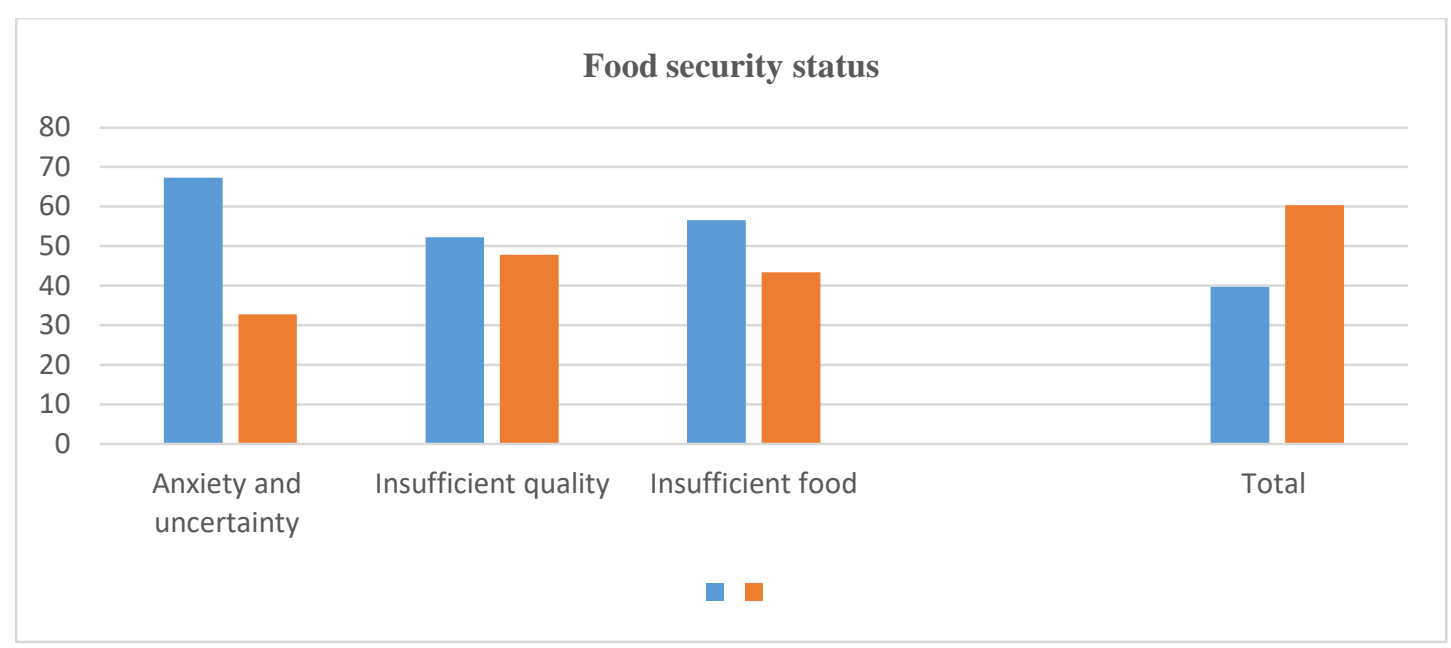

Figure 1: Food security status among refugees at all domains

\section{Source: Authors}

\section{Comparison of Food Security Status Among Syrian and Iraqi}

Table 5 below shows the food security status among Syrian and Iraqi refugees. The results indicate that Iraqi refugees were more food secure than Syrian refugees at all levels. Firstly, there are statistically significant differences among Syrian and Iraqi refugees in the anxiety and uncertainty domain $(\mathrm{p}=0.01<0.05)$. Similarly, the insufficient quality of Iraqi was greater than Syrian. There are statistically significant differences among Syrian and Iraqi refugees $(\mathrm{p}=0.02<$ 0.05). With regards to the third domain, there are statistically significant differences among Syrian and Iraqi refugees at insufficient food domain $(p=0.00<0.05)$. Finally, food security at a total level of Iraqi was greater than Syrian. There are statistically significant differences among Syrian and Iraqi refugees at the total level $(\mathrm{p}=0.01<0.05)$.

Table 5: Food security status of Syrian versus Iraqi refugees

\begin{tabular}{llllll}
\hline \multirow{2}{*}{ Domain } & \multicolumn{2}{l}{ Food secure } & \multicolumn{3}{l}{ P-value } \\
\cline { 2 - 6 } & \multicolumn{2}{l}{ Syrian } & \multicolumn{2}{l}{ Iraqi } & \\
\cline { 2 - 6 } & Mean & Std. Dev. & Mean & Std. Dev. & \\
\hline Anxiety and uncertainty & 0.41 & 0.49 & 0.26 & 0.44 & $0.01^{*}$ \\
\hline Insufficient quality & 0.44 & 0.50 & 0.59 & 0.49 & $0.02^{*}$ \\
\hline Insufficient food & 0.43 & 0.50 & 0.68 & 0.48 & $0.00^{*}$ \\
\hline Total & 0.30 & 0.46 & 0.47 & 0.50 & $0.01^{*}$ \\
\hline
\end{tabular}

$*, * *, * * *$ mean that significant difference at $1 \%, 5 \%$, and $10 \%$, respectively.

Source: Authors 


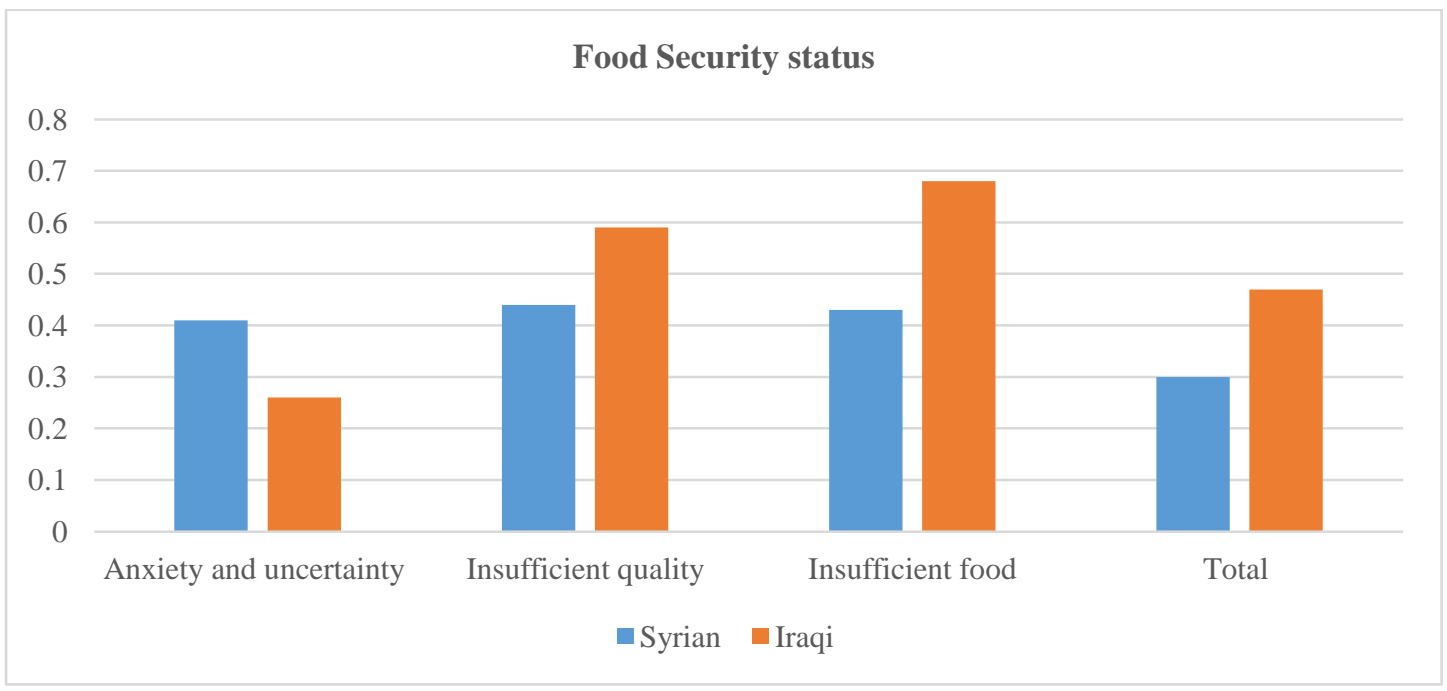

Figure 2: Food security status among Syrian versus Iraqi refugees

Source: Authors

\section{The occurrence of food security and socio-demographic variables}

Our analysis is designed to assess food security at the household level. For instance, it is considered essential to investigate the effect of different household variables on food security. The Pearson Chi-square difference tests were performed to examine the effect of socio-demographic and economic variables on food security status. Table 6 below shows the differences in food security status based on socio-demographic variables. Table 6 illustrates that no statistically significant associations were found between food security status and gender, marital status, household size, number of males, and number of households in the same house. Whereas the results of the Pearson Chi-square difference test showed that these variables had statistically significant associations with food security status, these variables are nationality (Iraqi refugees were more likely to be secure food $p=0.00<0.01$ ), number of females in the household (the family who had one female was more likely to be secure food $p=0.07<0.10$ ), age (the older age group was less likely to be secure food $p=0.06<0.10$ ), an education level (the higher education, the greater food security $p=0.03<0.05$ ), length stay in Turkey (the lower years, the greater food security $\mathrm{p}=0.04<0.05$ ), the households having a member in their countries (were less likely to be secure food $p=0.01<0.05$ ), and finally, place of residency or district ( living in Atakum were more likely to be food secure, followed by Ilkadim followed by Canik $\mathrm{p}=0.02<0.05$ ).

Table 6: The differences in food security status among socio-demographic variables

\begin{tabular}{llll}
\hline Socio-demographic Variables & Sub- variable & Mean Score & P-value \\
\hline Nationality & Syrian & 0.30 & $0.00^{*}$ \\
& Iraqi & 0.47 & \\
\hline Gender & Male & 0.36 & 0.16 \\
& Female & 0.45 & \\
\hline Marital status & Married & 0.34 & 0.13 \\
& Single & 0.46 & \\
& Divorced & 0.25 & \\
\hline Household size & Less 3 & 0.41 & 0.75 \\
& $3-4$ & 0.44 & \\
& $5-6$ & 0.40 & \\
& More 6 & 0.34 & 0.14 \\
Number of males & 1 Male & 0.39 & \\
& 2 Males & 0.44 & \\
\hline Number of females & 3 Males & 0.22 & $0.07^{* * *}$ \\
& 1 Female & 0.45 & \\
\hline Age years & Females & 0.30 & \\
& 3 Females & 0.43 & \\
& $18-25$ Years & 0.49 & $0.06^{* *}$ \\
& 26-35 Years & 0.29 & \\
\hline Education level & 36 - 45 Years & 0.39 & \\
& More than 45 Years & 0.39 & \\
\hline
\end{tabular}




\begin{tabular}{llll}
\hline & Secondary & 0.25 & \\
& High & 0.53 & \\
& Bachelor & 0.35 & \\
& Master and doctorate & 0.53 & \\
\hline Households number in the house & 1 Household & 0.41 & 0.20 \\
& 2 Households & 0.22 & \\
& 3 Households & 0.60 & \\
\hline Length residency in Turkey & Less than 3 years & 0.49 & $0.04^{* *}$ \\
& From 3 to 4 years & 0.42 & \\
& Above of 5 years & 0.30 & \\
\hline Family in your country & Yes & 0.35 & $0.02^{* *}$ \\
& No & 0.51 & \\
\hline District & Canik & 0.22 & $0.02^{* *}$ \\
& Atakum & 0.45 & \\
& Ilkadim & 0.38 & \\
\hline
\end{tabular}

$*, * *, * * *$ mean that significant difference at $1 \%, 5 \%$, and $10 \%$, respectively.

Source: Authors

\section{The occurrence of food security and economic variables}

Table 7 below shows the differences in food security status based on economic variables. Table 7 illustrates that no statistically significant associations were found between food security status and the number of workers per household (p $=0.13>0.01)$. Whereas the results of Pearson Chi-square difference test showed that these variables had statistically significant associations with food security status these variables are: job status (student had the best food security status followed by employed and unemployed were less likely to be food secure $p=0.07<0.10$ ), household income level (the higher income the higher food security $\mathrm{p}=0.00<0.01$ ), cash and kind assistance revealed the same results (who did not take cash and kind assistance were more likely to be food secure $\mathrm{p}=0.00<0.01$ and $\mathrm{p}=0.00<0,01$ respectively), career (who work in their career were more likely to be food secure $\mathrm{p}=0.06<0.10$ ), inflation effect (refugees who weren't influenced by inflation were likely to be more secure $\mathrm{p}=0.00<0.01$ ), vehicle ( respondents who had vehicle were more likely to be food secure $\mathrm{p}=0.09<0.10$ ), home items (respondents who had all items in their houses were more likely to be more food secure $\mathrm{p}=0.00<0.01$ ), the number of males in Turkey (respondents who eat three meals daily were more likely to be food secure followed by two meals $\mathrm{p}=0.00<0.01$ ).

Table 7: The differences in food security status among economic variables

\begin{tabular}{|c|c|c|c|}
\hline Variables & Sub- variable & Mean Score & $P$-value \\
\hline \multirow[t]{3}{*}{ Job-status } & No work & 0.29 & $0.07 * * *$ \\
\hline & I work & 0.39 & \\
\hline & Student & 0.48 & \\
\hline \multirow[t]{4}{*}{ Number of workers } & No person & 0.36 & 0.13 \\
\hline & One person & 0.47 & \\
\hline & Two persons & 0.29 & \\
\hline & Three persons & 0.67 & \\
\hline \multirow[t]{4}{*}{ Income level } & Less than $1500 \mathrm{TL}$ & 0.10 & $0.00 *$ \\
\hline & $1500-2000 \mathrm{TL}$ & 0.26 & \\
\hline & $2000-3000 \mathrm{TL}$ & 0.42 & \\
\hline & More than $3000 \mathrm{TL}$ & 0.58 & \\
\hline \multirow[t]{2}{*}{ Cash assistance } & Yes & 0.13 & $0.00 *$ \\
\hline & No & 0.44 & \\
\hline \multirow[t]{2}{*}{ Kind assistance } & Yes & 0.12 & $0.00 *$ \\
\hline & No & 0.43 & \\
\hline \multirow{2}{*}{ Career } & My career & 0.51 & $0.06 * * *$ \\
\hline & Another & 0.37 & \\
\hline \multirow[t]{2}{*}{ Consumption change } & Yes & 0.31 & $0.00 *$ \\
\hline & No & 0.61 & \\
\hline \multirow[t]{2}{*}{ Vehicle } & Yes & 0.53 & $0.09 * * *$ \\
\hline & No & 0.38 & \\
\hline \multirow[t]{2}{*}{ Items } & Every & 0.45 & $0.00 *$ \\
\hline & Not & 0.19 & \\
\hline \multirow[t]{3}{*}{ N. Meals in Turkey } & Two meals & 0.26 & $0.00 *$ \\
\hline & Three meals & 0.51 & \\
\hline & Four meals & 0.41 & \\
\hline
\end{tabular}


$*, * *, * * *$ mean that significant difference at $1 \%, 5 \%$, and $10 \%$, respectively.

\section{Source: Authors}

\section{DISCUSSION}

Our analysis was designed to assess food security for Syrian and Iraqi refugees living in Samsun, Turkey. In addition, to examine the associations between socio-demographic and economic variables and food security status. According to the results in table 5, the Iraqi refugees experienced better food security status at three domains and the total level. According to the findings, more than $67 \%$ of the refugees experienced food security status at anxiety and uncertainty domain, $52.2 \%$ and $56.6 \%$ of the refugees experienced food security status at the insufficient quality and insufficient food domains, respectively. These results ensure that food security levels could change by region, time, and population. Our results are consistent with (Pereira et al., 2021), which indicated that food insecurity depends on regional context.

Table 6 illustrates that nationality had significant impacts on food security status. Therefore, the first hypothesis is H1. There is a significant difference in food security status between Syrian and Iraqi refugees is accepted. The findings illustrate that insignificant associations were found between food security status and gender. These results are inconsistent with previous research_(Smith et al., 2017). Marital status had no significant effect on food security status. These results were in line with the study (Oberholser et al., 2004) and were inconsistent with previous research (Smith et al., 2017), where married people experienced more level of food security. Household size had no significant impacts on food security status. Compared with previous studies, it is concluded that the results were inconsistent with others (Iorlamen et al., 2014). Age had significant impacts on food security status (the older age group was less likely to be food secure). These results were consistent with (Smith et al., 2017; Omidvar et al., 2013), where the probability of food insecurity increases with older people. Education level had a significant effect on food security status. Our results were supported by similar studies on refugees (Hadley et al., 2007; Omidvar et al., 2013; Ifeoma and Agwa, 2014); these studies indicated that the probability of food security was higher with a high level of education. Length residency in Turkey significantly affected food security status, and the results were not in line with a previous study (Hadley et al., 2007). Our results may be explained that refugees in the initial years had savings. Finally, place of residency or district had a significant effect on food security status. Therefore, Therefore, H2. Socio-demographic variables that have a significant influence on food security can be partly accepted.

Table 7 below shows the differences in food security status based on economic variables. Table 7 illustrates that job status had a significant effect on food security status; these results are in line with the previous studies that employment increases the chances of being food secure (Smith et al., 2017; Titus and Adetokunbo 2007). Household income level had a significant effect on food security status. These results are in line with the previous studies that as income level increases, lower the probability of experiencing food insecurity (Ajani et al., 2006; Allee et al., 2021; Hadley et al., 2007; Larson et al., 2019; Park et al., 2019; Smith et al., 2017). But, the level of impact is not constant and varies depending on the countries (Allee et al., 2021). Income support programs and the generation of jobs should tackle food insecurity (Maitra, 2017). Some studies indicated that lack of off-farm income leads to food insecurity status (Abegaz, 2017). Cash and kind assistance variables had a significant effect on food security status. This explains that refugees who do not receive cash or kind assistance enjoy good economic status and do not meet the specified criteria. Career, inflation effect, ownership of a vehicle, and availability of all home items had statistically significant associations with food security status. Finally, the number of meals eaten in Turkey had a significant effect on food security status. Therefore, hypothesis H3. Economic variables that have a significant influence on food security can be partially accepted.

The current study tried to assess the food security status of Syrian and Iraqi refugees living in Samsun, Turkey. In addition, to examine if there are differences in food security level based on refugee's socio-demographic and economic variables. We used HFIAS indicators (three domains and 9-item) with two responses food secure and food insecure.

The results of our study pointed out that the proportion of food security decreases through moving from indicators into the domain. According to the results, $67.3 \%, 52.2 \%, 56.6 \%$, and $39.7 \%$ experienced food security at three domains and full food security, respectively. It is concluded from Table 5 that the food security status of Iraqi refugees was better than Syrian refugees at all levels. These results were explained that the economic status of Iraqi refugees was better. Likewise, there are a large number of Iraqis who have another source of income.

In examining the association between food security status and refugees' profiles, the current study revealed the presence of significant associations between used variables and food security status. Several socio-demographic variables had significant effects on food security, such as (nationality, age, level of education, length of stay in Turkey, and district) had significant effects on food security. Also, economic variables such as (job status and level of income) had significant effects on food security.

\section{CONCLUSION}

This study investigated the different factors influencing refugee households' food security in Samsun province of Turkey. The results of the study concluded that the level of food security decreases by moving from indicators into the domain. Thus, $67.3 \%$ of the refugee households experienced food secure through the first domain, $52.2 \%$ of the refugee 
households experienced food secure through the second domain, $56.6 \%$ of the refugee households experienced food secure through the third domain, and $39.7 \%$ of the refugee households experienced food secure through the total food security. Syrian refugees were worse than Iraqi refugees. A large number of Iraqis have another source of income, such as retirement salary from their homeland countries. Several socio-demographic variables such as nationality, age, level of education, length of stay in Turkey, and district had significant effects on the food security status of the refugee households. Also, economic variables such as job status and income level had significant effects on the food security status of the refugee households.

The level of food security is considered low, especially in a developed country such as Turkey. There is a need to improve the prevalence of food security. The policies in this field should be built by understanding the factors influencing food security. Food security governance can be improved by the identification of useful FI indicators for policymakers (Pérez-Escamilla et al., 2017). Therefore, the Turkish governmental and non-governmental organizations working in the food security field should focus on the economic status of refugees' households, especially the most vulnerable. This procedure can improve food security status and decrease the food insecurity status among refugees. Likewise, the current study recommends applying specific programs that could alleviate food insecurity among refugees. Finally, the current study recommends applying a new criterion to assess the refugee's status.

\section{LIMITATION AND STUDY FORWARD}

This study is conducted only in three urban districts of Samsun province of Turkey. Therefore, this study is delimited to three municipalities of Atakum, Ilkadim, and Canik. These three municipalities were selected because the majority of refugees have lived over there. In addition, the population in the current study is determined by Syrian and Iraqi refugees whereas, Turkey is hosting refugees from several countries. And the evaluation of food security of all refugees from all countries is considered important in future studies. Finally, the researchers based on FAO's scale to assess the food security of refugees. This scale is applied to assess food security in all countries whereas, the food security status is different from one country to another. Therefore, future studies should focus on developing new indicators to fit different situations and countries.

\section{ACKNOWLEDGEMENT}

The authors would like to thank all refugees who joined and responded to this study. In addition to, the authors are thankful to GIAP Journals, Editorial Board for sponsoring this research publication.

\section{AUTHORS CONTRIBUTION}

The first author wrote the introduction, literature review, methodology, data collection, data analysis, discussion, conclusion, and formating; the second author reviewed, edited, and validated.

\section{REFERENCES}

1. Abegaz, K. H. (2017). Determinants of food security: evidence from Ethiopian Rural Household Survey (ERHS) using pooled cross-sectional study. Agriculture \& Food Security, 6(1), 1-7. https://doi.org/10.1186/s40066-017-0153-1

2. Ajani, S. R., Adebukola, B. C., \& Oyindamola, Y. B. (2006). Measuring household food insecurity in selected local government areas of Lagos \& Ibadan, Nigeria. Pakistan Journal of Nutrition. 5 (1). $62-67$.

3. Alaimo, K., Olson, C. M., \& Frongillo, E. A. (2001). Food insufficiency \& American school-aged children's cognitive, academic, \& psychosocial development. Pediatrics, 108(1), 44-53.

4. Allee, A., Lynd, L. R., \& Vaze, V. (2021). Cross-national analysis of food security drivers: comparing results based on the Food Insecurity Experience Scale and Global Food Security Index. Food Security, 1-17. https://doi.org/10.1007/s12571-021-01156-w

5. Amugsi, D. A., Lartey, A., Kimani-Murage, E., \& Mberu, B. U. (2016). Women's participation in household decision-making and higher dietary diversity: findings from nationally representative data from Ghana. Journal of Health, Population and Nutrition, 35(1), 1-8. https://doi.org/10.1186/s41043-016-0053-1

6. Asadullah, M. N., \& Kambhampati, U. (2021). Feminization of farming, food security and female empowerment. Global Food Security, 29, 100532. https://doi.org/10.1016/j.gfs.2021.100532

7. Berry, E. M., Dernini, S., Burlingame, B., Meybeck, A., \& Conforti, P. (2015). Food security \& sustainability: can one exist without the other? Public Health Nutrition, 18(13). 2293-2302. https://doi.org/10.1017/S13689 $8001500021 X$ X Opens in a new window]

8. Carroll, J., Epstein, R., Fiscella, K., Volpe, E., Diaz, K., \& Omar, S. (2007). Knowledge \& beliefs about health promotion \& preventive health care among Somali women in the United States. Health Care for Women International, 28(4). 360-380. https://doi.org/10.1080/07399330601179935

9. Dharod, J. M., Croom, J. E., \& Sady, C. G. (2013). Food insecurity: its relationship to dietary intake \& body weight among Somali refugee women in the United States. Journal Of Nutrition Education \& Behavior, 45(1), 47-53. https://doi.org/10.1016/j.jneb.2012.03.006

10. FAO (2009). Declaration of the World Summit on Food Security. FAO, Rome, World Summit on Food Security. 
11. FAO (2009). Food \& Agriculture Organization of the United Nations. (Accessed 01.01.2020). http://www.fao.org/faostat/en/\#data/QC.

12. Farrukh, M. U., Bashir, M. K., Hassan, S., Adil, S. A., \& Kragt, M. E. (2020). Mapping the food security studies in India, Pakistan and Bangladesh: Review of research priorities and gaps. Global Food Security, 26, 100370. https://doi.org/10.1016/j.gfs.2020.100370

13. Fernandes, S. G., Rodrigues, A. M., Nunes, C., Santos, O., Gregório, M. J., de Sousa, R. D., Dias, S., \& Canhão, H. (2018). Food insecurity in older adults: Results from the epidemiology of chronic diseases cohort study 3. Frontiers in Medicine, 5(203). https://doi.org/10.3389/fmed.2018.00203

14. Frongillo, E. A., Nguyen, H. T., Smith, M. D., \& Coleman-Jensen, A. (2017). Food insecurity is associated with subjective well-being among individuals from 138 countries in the 2014 Gallup World Poll. The Journal of Nutrition, 147(4), 680-687. https://doi.org/10.3945/jn.116.243642

15. Galiè, A., Teufel, N., Girard, A. W., Baltenweck, I., Dominguez-Salas, P., Price, M. J., ... \& Yount, K. M. (2019). Women's empowerment, food security and nutrition of pastoral communities in Tanzania. Global Food Security, 23, 125-134. https://doi.org/10.1016/j.gfs.2019.04.005

16. Hadley, C., \& Sellen, D. (2006). Food security \& child hunger among recently resettled Liberian refugees \& asylum seekers: a pilot study. Journal of Immigrant \& Minority Health, 8(4), 369-375. https://doi.org/1 .1007/s10903-006-9007-9

17. Hadley, C., Zodhiates, A., \& Sellen, D. W. (2007). Acculturation, economics \& food insecurity among refugees resettled in the USA: a case study of West African refugees. Public Health Nutrition, 10(4), 405-412. https://doi.org/10.1017/S1368980007222943

18. Ifeoma, I., \& Agwu, A. (2014). Assessment of food security situation among farming households in rural areas of Kano State, Nigeria. Journal of Central European Agriculture,15(1), 94-107. https://doi.org/10.5513/j cea.v15i1.2443

19. IOM (2020). World migration report. Accessed: 01 January 2020. https://www.iom.int/.

20. Iorlamen, T. R., Abu, G. A., \& Lawal, W. L. (2014). Assessment of expenditure on food among urban households \& it's implication for food security: Evidence from Benue State, Nigeria. African Journal of Food, Agriculture, Nutrition \& Development, 14(2).

21. Larson, J. B., Castellanos, P., \& Jensen, L. (2019). Gender, household food security, and dietary diversity in western Honduras. Global Food Security, 20, 170-179. https://doi.org/10.1016/j.gfs.2019.01.005

22. Maitra, C. (2017). Adapting an experiential scale to measure food insecurity in urban slum households of India. Global Food Security, 15, 53-64. https://doi.org/10.1016/j.gfs.2017.04.005

23. Melgar-Quinonez, H., \& Hackett, M. (2008). Measuring household food security: the global experience. Revista de Nutrição, 21, 27s-37s. https://doi.org/10.1590/S1415-52732008000700004

24. Mota, A. A., Lachore, S. T., \& H \& iso, Y. H. (2019). Assessment of food insecurity \& its determinants in the rural households in Damot Gale Woreda, Wolaita zone, southern Ethiopia. Agriculture \& Food Security, 8(1), 11. https://doi.org/10.1186/s40066-019-0254-0

25. Oberholser, C. A., \& Tuttle, C. R. (2004). Assessment of household food security among food stamp recipient families in Maryland. American Journal of Public Health, 94(5), 790-795.

26. Omidvar, N., Ghazi-Tabatabie, M., Sadeghi, R., Mohammadi, F., \& Abbasi-Shavazi, M. J. (2013). Food insecurity \& its sociodemographic correlates among Afghan immigrants in Iran. Journal Of Health, Population, \& Nutrition, 31(3), 356.

27. Nunnery, D. L., \& Dharod, J. M. (2017). Potential determinants of food security among refugees in the US: an examination of pre-\& post-resettlement factors. Food Security, 9(1), 163-179. https://doi.org/10.1007/s12571016-0637-Z

28. Park, J. Y., Ville, A. S., Schwinghamer, T., \& Melgar-Quiñonez, H. (2019). Heterogeneous factors predict food insecurity among the elderly in developed countries: Insights from a multi-national analysis of 48 countries. Food Security, 11(3), 541-552. https://doi.org/10.1007/s12571-019-00934-X

29. Peng, W., \& Berry, E. M. (2018). Global nutrition 1990-2015: A shrinking hungry, and expanding fat world. PLoS ONE 13(3), e0194821. https://doi.org/10.1371/journal.pone.0194821

30. Pereira, A., Handa, S., \& Holmqvist, G. (2021). Estimating the prevalence of food insecurity of households with children under 15 years, across the globe. Global Food Security, 28, 100482. https://doi.org/10.1016/j. gfs.2020.100482

31. Pérez-Escamilla, R., Gubert, M. B., Rogers, B., \& Hromi-Fiedler, A. (2017). Food security measurement \& governance: Assessment of the usefulness of diverse food insecurity indicators for policy makers. Global Food Security, 14, 96-104. https://doi.org/10.1016/j.gfs.2017.06.003

32. Price, M., Galie, A., Marshall, J., \& Agu, N. (2018). Elucidating linkages between women's empowerment in livestock and nutrition: a qualitative study. Development in Practice, 28(4), 510-524.https://doi.org/10.10 $\underline{80 / 09614524.2018 .1451491}$

33. Ramakrishna, G., \& Demeke, A. (2002). An empirical analysis of food insecurity in Ethiopia: the case of North Wello. Africa Development/Afrique et Développement, 27 (1/2), 127-143. 
34. Sadiddin, A., Cattaneo, A., Cirillo, M., \& Miller, M. (2019). Food insecurity as a determinant of international migration: evidence from Sub-Saharan Africa. Food Security, 11(3), 515-530. https://doi.org/10.1007/s12571019-00927-w

35. Saint Ville, A., Po, J. Y. T., Sen, A., Bui, A., \& Melgar-Quiñonez, H. (2019). Food security \& the Food Insecurity Experience Scale (FIES): ensuring progress by 2030. Food Security, 11, 483-491. https://doi.org/10. 1 007/s12571-019-00936-9

36. Shobe, M. A., Narcisse, M. R., \& Christy, K. (2018). Household financial capital and food security. Journal of Poverty, 22(1), 1-22. https://doi.org/10.1080/10875549.2017.1348426

37. Sinharoy, S. S., Waid, J. L., Ali, M., Yount, K. M., \& Thilsted, S. (2019). Resources for women's agency, household food security, and women's dietary diversity in urban Bangladesh. Global Food Security, 23, 1-8. https://doi.org/10.1016/i.gfs.2019.03.001

38. Smith, M. D., Kassa, W., \& Winters, P. (2017). Assessing food insecurity in Latin America \& the Caribbean using FAO's food insecurity experience scale. Food Policy, 71, 48-61. https://doi.org/10.1016/j.food pol.2017.07.005

39. Titus, B., \& Adetokunbo, G. (2007). An analysis of food security situation among Nigerian urban households: Evidence from Lagos State, Nigeria. Journal of Central European Agriculture. 8 (3). 397-406.

40. UNHCR (2019). Turkey fact sheet. Accessed: 01 January 2020, https://reporting.unhcr.org/turkey

41. Vilar-Compte, M., Gaitán-Rossi, P., \& Pérez-Escamilla, R. (2017). Food insecurity measurement among older adults: Implications for policy \& food security governance. Global Food Security, 14, 87-95. https://doi.org/10.1016/j.gfs.2017.05.003

42. WFP, (2019). World food programme. (Accessed on 01-09-2020). https://www.wfp.org/publications/2019hunger-map

43. Woertz, E. (2017). Food security in Iraq: results from quantitative and qualitative surveys. Food Security, 9(3), 511-522. https://doi.org/10.1007/s12571-017-0666-2

44. Yikii, F., Turyahabwe, N., \& Bashaasha, B. (2017). Prevalence of household food insecurity in wetland adjacent areas of Uganda. Agriculture \& food security, 6(1), 63. https://doi.org/10.1186/s40066-017-0147-Z 